KIMIKA Volume 30, Number 2, pp. 28- 38 (2019)

(C) 2019 Kapisanang Kimika ng Pilipinas

All rights reserved. Published in the Philippines.

ISSN 0115-2130 (Print); 2508-0911 (Online)

https://doi.org/10.26534/kimika.v30i2.28-38

\title{
Analysis of Inorganic Arsenic [As[III] and Total As] and Some Physicochemical Parameters in Groundwater Samples from Selected Areas in Bulacan, Batangas, and Laguna, Philippines
}

\author{
Maritess L. Magalona ${ }^{1}$, Milagros M. Peralta ${ }^{1}$, Marivic S. Lacsamana ${ }^{1}$, Veronica C. Sabularse ${ }^{1}$, \\ Amado B. Pelegrina ${ }^{1}$ and Constancio C. de Guzman ${ }^{2}$ \\ ${ }^{1}$ Institute of Chemistry, College of Arts and Sciences, University of the Philippines Los Baños, College, \\ Laguna, Philippines 4031
}

2 Institute of Crop Science, College of Agriculture and Food Science, University of the Philippines Los Baños, College, Laguna, Philippines 4031

\begin{abstract}
Numerous cases of arsenic (As) poisoning from contaminated groundwater have been reported worldwide including the Philippines. The maximum contamination limit has been set by World Health Organization (WHO) for arsenic in drinking water at $10 \mathrm{ppb}$. This study determined the As(III) and total As content of groundwater samples in selected sites of Bulacan, Batangas, and Laguna by differential pulse anodic stripping voltammetry (DPASV). The $\mathrm{pH}$, temperature, conductivity, total solids, turbidity, and salinity of the groundwater samples were also determined during sample collection. Groundwater samples from Laguna were naturally warm, with collection temperatures exceeding $30^{\circ} \mathrm{C}$, compared to water samples from Batangas and Bulacan $\left(\left(\mathrm{T}=27\right.\right.$ to $\left.29.5^{\circ} \mathrm{C}\right)$. The $\mathrm{pH}$ and turbidity of all samples were found to comply with the limits based on acceptability set by the WHO and the Philippine National Standards for Drinking Water (PNSDW). However, some samples had total dissolved solids and salinity beyond the limits set by the WHO and PNSDW guidelines. Moreover, some of the samples tested contained arsenite As(III), the more toxic form of arsenic, above $10 \mathrm{ppb}$ whereas only one water sample tested had less than $10 \mathrm{ppb}$ total arsenic content.
\end{abstract}

Keywords: arsenic, groundwater, differential pulse anodic stripping voltammetry, Philippines

\footnotetext{
*Author to whom correspondence should be addressed; email: mlmagalona@up.edu.ph
} 


\section{INTRODUCTION}

Arsenic is a naturally occurring element that humans typically encounter since it is widely distributed in the earth's crust. It is present in the soil, sediments, water, air, and in living organisms as well. Mobilization of arsenic is affected by climate, complexation of arsenic with organic and inorganic components, biological activity, and redox potential status (Jain and Ali, 2000; Mandal and Suzuki, 2002). Agricultural applications include pesticides, wood preservatives, and feed additives. Industrial uses include electronics, pigments, mining, and in metallurgy, as catalyst and alloy (Mandal and Suzuki, 2002; Hughes et al., 2011). This element plays a controversial role in human history because of its use as a poison. Known as the "king of poisons" because of its potency and low traceability, it is also known as the "poison of kings" because it was used during the Middle Ages and Renaissance period to remove rivals of the members of the ruling class (Hughes et al., 2011).

The contamination of water by arsenic, even at high concentrations, is not accompanied by any change in taste, smell, color, or visible appearance which makes it hard to detect (Arifin et al., 2013). Arsenic contamination of groundwater has led to major environmental issues in various countries. One of the largest outbreaks of poisoning occurred in
Bangladesh (Mandal and Suzuki, 2002; Khan and Ho, 2011) where elevated levels of arsenic were observed in drinking water supplies for more than 70 million people. This has been attributed to the digging of tube-wells for drinking water and irrigation purposes which resulted to the mobilization of arsenic in the exposed soil. Other countries that are reported to have high levels of arsenic in water include India, Cambodia, the Lao People's Democratic Republic, Myanmar, Pakistan, Nepal, Cambodia, Vietnam, China, Iran, Thailand, Taiwan, England, Chile, Mexico, Argentina, Canada, and United States. The current recommended exposure level of arsenic in drinking water was set by the World Health Organization (WHO) and Environmental Protection Agency (EPA) at $10 \mu \mathrm{g} / \mathrm{L}$ or $10 \mathrm{ppb}$ (Feeney and Kounaves, 2002; Khan and Ho, 2011). Above this level, symptoms manifest as a sign of acute or chronic toxicity. Acute arsenic toxicity results in gastrointestinal discomfort, diarrhea, vomiting, bloody urine, anuria, convulsions, shock, coma, and death. On the other hand, chronic toxicity produces non-malignant skin lesions like hypopigmentation, hyperpigmentation, and hyperkeratosis and can lead to cancer of the skin and different internal organs (Jain and Ali, 2000; Hughes et al., 2011; Sy et al., 2017). Table 1 displays the lifetime risks of cancer from drinking tap water that are contaminated with different levels of arsenic.

Table 1. Lifetime risks of dying of cancer from arsenic in tap water (National Resource Defense Council, 2000).

\begin{tabular}{cc}
\hline $\begin{array}{c}\text { Arsenic Level in Tap Water } \\
\text { (in parts per billion, or ppb) }\end{array}$ & $\begin{array}{c}\text { Approximate Total Cancer Risk } \\
\text { (assuming } 2 \text { liters consumed/day) }\end{array}$ \\
\hline $0.5 \mathrm{ppb}$ & 1 in 10,000 \\
$1 \mathrm{ppb}$ & 1 in 5,000 \\
$3 \mathrm{ppb}$ & 1 in 1,667 \\
$4 \mathrm{ppb}$ & 1 in 1,250 \\
$5 \mathrm{ppb}$ & 1 in 1,000 \\
$10 \mathrm{ppb}$ & 1 in 500 \\
$20 \mathrm{ppb}$ & 1 in 250 \\
$25 \mathrm{ppb}$ & 1 in 200 \\
\hline
\end{tabular}

* highest cancer risk EPA usually allows in tap water 
Since 2015 arsenic poisoning incidents were reported in several areas in Central Luzon. To address this, former President Benigno Aquino III signed Administrative Order No. 47 on August 26, 2015 which created the Interagency Task Force on Arsenic Risk Reduction (Office of the President of the Philippines, 2015). The Department of Health (DOH)Central Luzon Regional Office announced that there were 17 confirmed cases out of 100 people who tested positive for high levels of arsenic and manifested hyperkeratosis (Sun.Star Pampanga, 2015). In June 2016, the former DOH Secretary Janette Garin updated that already 123 arsenicosis cases were recorded (Santos, 2016; Sun.Star Manila, 2016). The study of Sy et al. (2017), conducted at the University of the Philippines, Philippine General Hospital, reported that among the 116 residents screened from Luzon in 2014, 81 tested positive for arsenic keratosis and hyperpigmentation. These cases were attributed to high levels of arsenic in tap water and topsoil.

The objective of this study was to analyze the arsenic content of groundwater samples in selected sites of Bulacan, Batangas, and Laguna to determine if the groundwater resources in these areas are safe for public usage and oral consumption. Hence, this study will inform and forewarn the communities living in the area about the possible risks that can emanate from the possible arsenic contamination. Also, some important physicochemical parameters of water like $\mathrm{pH}$, temperature, conductivity, total dissolved solids, and salinity were determined in order to give the residents an idea of the quality of the groundwater source for drinking and cooking purposes.

\section{EXPERIMENTAL}

Chemicals. The reagents used were ensured to be of highest purity. Analytical grade hydrochloric acid was from JT Baker. For the preparation of the aqueous solutions, deionized distilled water was used. As(III) and
As(V) solutions were prepared from sodium (meta)arsenite (Sigma Aldrich) and sodium arsenate heptahydrate (JT Baker), respectively.

Instruments. The arsenic contents (As(III) and As(V)) were analyzed using differential pulse anodic stripping voltammetry (DPASV) utilizing eDAQ potentiostat and e-corder 410 with ET076 gold disk as the working electrode, ET078 Pt/Ti rod as the auxiliary electrode, and BASI $\mathrm{Ag} / \mathrm{AgCl}$ as the reference electrode. On the other hand, Horiba U-10 multiparameter water quality checker was used to determine some physicochemical parameters of water samples. These include $\mathrm{pH}$, temperature, conductivity, total solids, turbidity, and salinity.

Water Sampling. Groundwater samples were collected from selected sites in Bulacan, Batangas, and Laguna. Sampling sites were selected by surveying the household areas in Bulacan, Batangas (near Mt. Taal), and Laguna (near Mt. Makiling) that have water pump or groundwater sources. In Bulacan, the sampling sites are in the middle of the rice field and are perennially flooded. Figure 1 shows the sampling sites. Purging of the pump source was carried out according to standard protocols (USGS, 2006) prior to obtaining groundwater samples. The water pump was pumped continuously for ten minutes so that possible interferences in the analysis were removed. Some physicochemical parameters ( $\mathrm{pH}$, temperature, conductivity, total solids, turbidity, and salinity) of water sample were measured on-site. A water sample was collected in a clean bottled container which was filled with water to the brim and was stored in an ice box. The collected water samples were then acidified $(1 \mathrm{~mL}$ concentrated $\mathrm{HCl}$ per $500 \mathrm{~mL}$ water sample; $\mathrm{pH}<2$ ) and stored in the refrigerator $(\mathrm{T}=4$ oC) prior to arsenic analysis. 


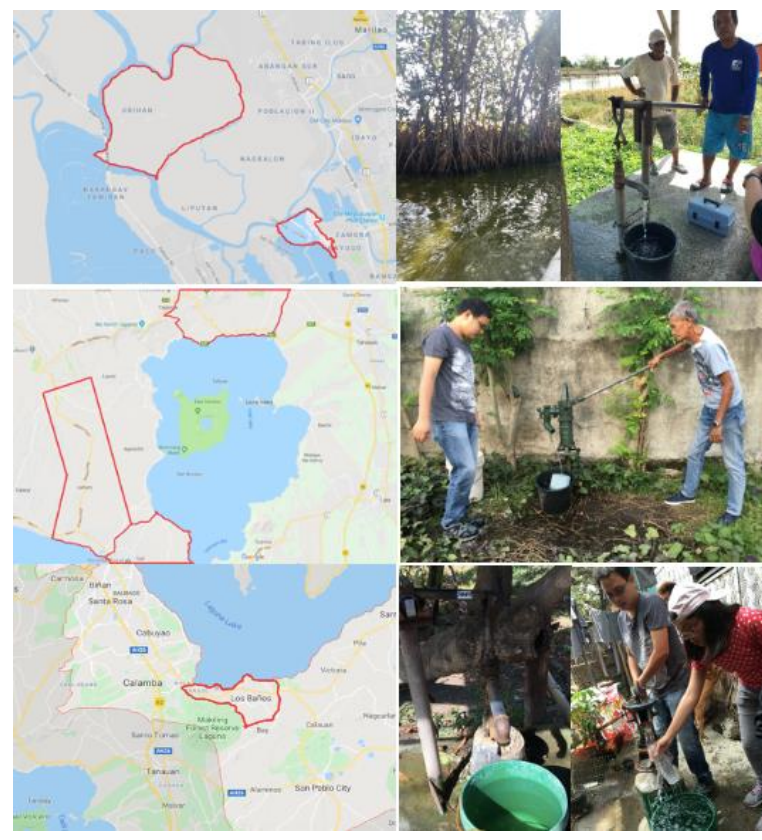

Figure 1. Map of the sampling sites (encircled in red) in Bulacan (top), Batangas (middle), and Laguna (bottom).

Arsenic Analysis. The arsenic contents of the groundwater samples were analyzed by differential pulse anodic stripping voltammetry (DPASV) using the developed and optimized parameters of Magalona et al. (2018) as shown on Table 2. Analysis for As(III) was done directly while for As(V), the sample was reduced with cysteine to As(III) prior to DPASV analysis and $\mathrm{As}(\mathrm{V})$ concentration was obtained by difference. Standard concentrations of 0 to $100 \mathrm{ppb}$ for
As(III) and As(V) were used to determine the exact concentrations of As(III) and total As $(\mathrm{As}(\mathrm{III})+\mathrm{As}(\mathrm{V}))$ in groundwater samples.

\section{RESULTS AND DISCUSSION}

Groundwater samples were collected from Bulacan, Batangas and Laguna. Bulacan was selected because it is one of the provinces in central Luzon and the data generated in this study provides additional information on the arsenic levels of the groundwater samples in the area. On the other hand, Batangas and Laguna were selected because these provinces are near to volcanic sites: Mt. Taal for Batangas, and Mt. Makiling for Laguna. Volcanism is one of the major contributing factors for naturally high levels of arsenic, thus arsenic contents are reported to be high around volcanic areas (Hughes et al., 2011; Khan and Ho, 2011). Residents in the selected sites actively use the groundwater samples for their daily activities. It is noteworthy that some residents in Bulacan use the groundwater sources for cooking and drinking.

Prior to arsenic analysis, some physicochemical parameters were analyzed on-site during sampling. These physicochemical parameters, which include $\mathrm{pH}$, temperature, conductivity, total dissolved solids, turbidity, and salinity, are important

Table 2. The optimized parameters for As(III) and As(V) analysis using DPASV (Magalona et al. 2018).

\begin{tabular}{cc}
\hline Parameters & Values \\
\hline Deposition Potential, V & -0.25 \\
Deposition Time, s & 180 \\
Identity of Supporting Electrolyte & Hydrochloric Acid \\
Concentration of Supporting Electrolyte, $\mathrm{M}$ & 1.0 \\
Rest Time, s & 10 \\
Scan Rate, V/s & 0.05 \\
Chemical reductant for the conversion of As(V) & L-cysteine \\
\hline
\end{tabular}


indicators for the quality of drinking water (WHO, 2011). Table 3 presents the safe limits set by the WHO and the Philippine National Standards (PNS) for drinking water.

The pH of water, although no health-based guideline value is proposed, is one of the most important operational water quality parameters. A guideline value $\mathrm{pH}$ range of 6.5 to 8.5 is established based on aesthetic considerations. This $\mathrm{pH}$ range prevents corrosion and breakdown of water treatment facilities (WHO, 2011). The $\mathrm{pH}$ values of all groundwater samples (Table 4) are within the guideline value $\mathrm{pH}$ range.

There are no guidelines for water temperature, although it is an important indicator for the palatability of water. Generally, cool water is more palatable than warm water which can enhance the growth of microorganisms and can cause problems related to taste, odor, color, and corrosion (WHO, 2011). Based on Table 4, groundwater samples from Laguna were classified as warm ( $\mathrm{T}>30 \mathrm{oC}$ ). In fact, some of these sampling sites were hot springs.
Electrical conductivity is the ability of a medium like water to carry an electric current. This ability is directly related to the concentrations of ions in the form of dissolved solids in water (WHO, 2011). Thus, the higher the conductivity, the higher the total dissolved solids (TDS). No health-based guideline values are proposed for conductivity and TDS, however guideline values for TDS are set based on acceptability to the consumers. Water samples that have good palatability have TDS values less than $600 \mathrm{mg} / \mathrm{L}$ while values greater than $1000 \mathrm{mg} / \mathrm{L}$ are considered unpalatable (WHO, 2011). Two groundwater samples were found to contain TDS greater than $1000 \mathrm{mg} / \mathrm{L}$ (Table 4). These were Sample 3 from Bulacan and Sample 5 from Batangas.

Turbidity, or the cloudiness, is caused by suspended or colloidal particles that obstruct light transmission through the water. These particles may attract microorganisms and serve to nourish their growth and reproduction; hence a guideline value of 5 NTU is set (WHO, 2011; PNS 2017). The NTU values of all groundwater samples (Table 4) are within the guideline range.

Table 3. Safe limits of WHO and PNS for drinking water (WHO, 2011; PNSDW, 2017)

\begin{tabular}{cccc}
\hline Parameter & WHO Limits & Philippine Limits* & Concentration, $\mathrm{mg} / \mathrm{mL}$ \\
\hline $\mathrm{pH}$ & $6.5-8.5$ & $6.5-8.5$ & 0.00000 \\
$\begin{array}{c}\text { Temperature, oC } \\
\text { Conductivity, } \\
\mu \mathrm{S} / \mathrm{cm}\end{array}$ & not specified & not specified & 0.02445 \\
$\begin{array}{c}\text { Total dissolved } \\
\text { solids (TDS), } \\
\text { mg/L }\end{array}$ & 1000 & not specified & 0.04890 \\
$\begin{array}{c}\text { Turbidity, NTU } \\
\text { Salinity, } \%\end{array}$ & not specified & 600 & 0.09780 \\
\hline
\end{tabular}

*based on Philippine National Standards for Drinking Water 
Table 4. Some physicochemical parameters, arsenic (III) and total arsenic content of groundwater samples.

\begin{tabular}{|c|c|c|c|c|c|c|c|c|c|}
\hline Sampling Site & $\begin{array}{l}\text { Sample } \\
\text { Number }\end{array}$ & $\mathrm{pH}$ & $\mathrm{T},{ }^{\circ} \mathrm{C}$ & $\begin{array}{c}\text { Conductivity, } \\
\mu \mathrm{S} / \mathrm{cm}\end{array}$ & $\begin{array}{c}\text { Total } \\
\text { Dissolved } \\
\text { Solids, mg/L }\end{array}$ & Turbidity, NTU & Salinity, \% & $\begin{array}{l}\text { As(III), } \\
\text { ppb }\end{array}$ & $\begin{array}{l}\text { Total As, } \\
\text { ppb }\end{array}$ \\
\hline \multirow{9}{*}{$\begin{array}{c}\text { Bulacan } \\
\text { (Meycauayan } \\
\text { and Marilao) }\end{array}$} & 1 & 8.31 & 28.9 & 796 & 522.6 & 1.85 & 3.00 & 1.996 & 32.52 \\
\hline & 2 & 7.89 & 29 & 4714 & 3492 & 2.09 & 2.00 & 21.733 & 26.30 \\
\hline & 3 & 7.88 & 28.6 & 1697 & 1163 & 2.5 & 1.00 & ND & 11.14 \\
\hline & 4 & 8.43 & 29 & 743 & 481.4 & 3.59 & 0.00 & 10.743 & 22.24 \\
\hline & 5 & 8.32 & 28.7 & 735.3 & 481.1 & 1.58 & 2.00 & 4.183 & 26.03 \\
\hline & 6 & 7.32 & 28.4 & 1086 & 725.1 & 1.02 & 2.00 & ND & 9.66 \\
\hline & 7 & 8.22 & 28.7 & 420 & 268.7 & 3.92 & 0.00 & ND & 30.22 \\
\hline & 8 & 6.93 & 27.6 & 1418 & 960.6 & 3.92 & 4.00 & ND & 15.61 \\
\hline & 9 & 7.08 & 27.9 & 1322 & 891.1 & 2.5 & 0.00 & ND & 14.80 \\
\hline \multirow{7}{*}{$\begin{array}{c}\text { Batangas } \\
\text { (Lemery, } \\
\text { Talisay, and } \\
\text { Taal) }\end{array}$} & 1 & 6.87 & 26 & 654.2 & 428.3 & - & 2.00 & ND & 20.88 \\
\hline & 2 & 7.22 & 26.5 & 678 & 446.3 & 1.35 & 3.00 & ND & 35.23 \\
\hline & 3 & 6.78 & 27.1 & 681 & 445.3 & 1 & 3.00 & ND & 20.21 \\
\hline & 4 & 6.79 & 27.7 & 764.6 & 501.7 & - & 2.00 & 1.884 & 21.83 \\
\hline & 5 & 7.53 & 29.5 & 1984 & 1377 & 2.05 & 4.00 & ND & 24.00 \\
\hline & 6 & 7.03 & 29 & 1374 & 930.7 & - & 0.00 & ND & 54.44 \\
\hline & 7 & 7.33 & 29.3 & 1227 & 824.4 & 2.19 & 0.00 & ND & 34.55 \\
\hline \multirow{7}{*}{$\begin{array}{c}\text { Laguna } \\
\text { (Pansol and } \\
\text { Los Baños) }\end{array}$} & 1 & 7.00 & 35.0 & 576 & 369 & - & 0.02 & ND & 37.37 \\
\hline & 2 & 7.00 & 32.0 & 518 & 331 & - & 0.02 & ND & 37.95 \\
\hline & 3 & 7.00 & 40.0 & 1150 & 736 & - & 0.05 & 3.622 & 333.02 \\
\hline & 4 & 7.00 & 39.0 & 639 & 409 & - & 0.02 & 37.096 & 113.56 \\
\hline & 5 & 6.00 & 40.0 & 518 & 331 & - & 0.02 & ND & 103.14 \\
\hline & 6 & 6.00 & 33.0 & 485 & 310 & - & 0.02 & ND & 35.23 \\
\hline & 7 & 6.00 & 37.0 & 644 & 412 & - & 0.02 & 1.548 & 32.66 \\
\hline
\end{tabular}

Note: "-" means no value generated from the Horiba U-10 multimeter

"ND" means not detected; LOD for As(III) = $2.24 \mathrm{ppb}$ 
No health-based guideline value is proposed for salinity (WHO, 2011). The EPA, however, imposes guideline values based on the Australian Drinking Water guidelines (Table 5). The guideline unit is in ppm (mg/L) while the data presented in Table 3 is in percent. Converting percent to $\mathrm{mg} / \mathrm{L}$, the highest salinity value of $4 \%$ equals $40,000 \mathrm{ppm}$. Based on Table 4, only few groundwater samples have good palatability based on salinity. These were Samples 4, 7 and 9 from Bulacan, 6 and 7 from Batangas, and all samples from Laguna. Palatability is subjective because, despite the high salinity of water in their area Bulakeños love the taste of their groundwater as compared to distilled water.

The arsenic content of the groundwater samples was analyzed using DPASV. This method was selected because of its low detection limit, low maintenance cost, high sensitivity, and high selectivity. Anodic stripping voltammetry is widely used for quantitative determination of specific ions. This method is known for its low detection limit (ppb levels) (Forsberg et al., 1975; Bodewig et al., 1982; Feeney and Kuonaves, 2002). It involves two major steps: deposition and stripping. The deposition step makes this method more sensitive and allows it to attain low detection limits (Robinson et al., 2005; Skoog et al., 2010) because preconcentration of the analyte, in this case As(III), takes place, at the electrode surface by depositing and reducing it to $\operatorname{As}(0)$. The amount of arsenic deposited is proportional to arsenic's concentration in the solution. Hence, quantification can be made in terms of signal and concentration (Robinson et al., 2005). The stripping step involves stripping the arsenic from the electrode's surface by oxidizing As(0) back to As(III). Various waveforms can be used during the stripping step. This includes linear scan, square-wave, staircase, and differential pulse. Among these waveforms, the differential pulse stripping offers high sensitivity and the highest signal-to-noise ratio (Copeland and Skogerboe, 1974; Forsberg et al., 1975). This waveform applies large amplitude (0.05 to $0.1 \mathrm{~V})$ pulses periodically in increasing manner. The Faradaic current or signal (si) is measured before and after a pulse, and the difference of the two currents gives rise to the peak-shaped voltammogram. The total arsenic in the sample is the summation of As(III) and As(V) present in the sample. To analyze As(V), the sample must be electrochemically reduced or deposited at a highly negative potential, which is at $-1.2 \mathrm{~V}$ (Salaun et al., 2007) or chemically reduced to As(III) (Feeney and Kuonaves, 2002). In this study L-cysteine was used to reduce $\mathrm{As}(\mathrm{V})$ to $\mathrm{As}(\mathrm{III})$. The limits of detection (LOD) using this method for As(III) and As(V) were determined to be 2.24 and $6.96 \mathrm{ppb}$, respectively. Table 4 indicates the As(III) and total As of groundwater samples. For As(III), the more toxic form of arsenic, most of the groundwater samples had undetectable concentrations. However, 3 groundwater samples had As(III) content above $10 \mathrm{ppb}$, the maximum contamination limit set by the EPA. These are Samples 2 ([As(III)] = $21.73 \mathrm{ppb})$ and 4 ([As(III)] = 10.74 ppb) from Bulacan, and Sample 4 ([As(III)] = $37.10 \mathrm{ppb}$ ) from Laguna. Among all the samples, only one groundwater sample (Sample 6 from Bulacan) had a total arsenic concentration below $10 \mathrm{ppb}$. It is also notable that samples 3 to 5 from Laguna had more than $100 \mathrm{ppb}$ total As and the temperatures during sample collection were high ( $\mathrm{T}=39-40 \mathrm{oC})$. The unusually high levels of arsenic and the naturally high temperature of water indicate that these groundwater samples came from aquifers near Mt. Makiling, a dormant volcano in the area. 
Table 5. EPA guidelines for salinity of drinking water (EPA South Australia, 2019).

\begin{tabular}{ccc}
\hline Salinity, mg/L & Percent Equivalent (\%) & Quality \\
\hline $0-600$ & $0-0.06$ & good \\
$600-900$ & $0.06-0.09$ & fair \\
$900-1,200$ & $0.09-0.12$ & poor \\
$>1,200$ & $>0.12$ & unacceptable (unpalatable) \\
Turbidity, NTU & 5 & 5 \\
\hline
\end{tabular}

It is worth noting that the major arsenic species found in Sample 3 from Laguna which gave the highest total arsenic content of 333 ppm was arsenate $(\mathrm{As}(\mathrm{V}))$. This sample had a low concentration of As(III) which was below the maximum contamination limit for drinking water. As(III) is six times more toxic than As(V). This study confirms that most groundwater supplies, especially areas near volcanic site, have high arsenic content. The high levels of arsenic in groundwater is attributed to the geochemical features and mobility of naturally occurring arsenic in the earth's crust (Mandal and Suzuki, 2002; Smedley and Kinniburgh, 2002).

There is little information about the occurrence of arsenic in groundwater resources in the Philippines. The study of Torres et al. (2010) determined the presence of arsenic, cadmium, and lead in drinking water supplies in Metro Manila using inductively coupled plasma mass spectrometry (ICP-MS). All water samples except from Muntinlupa had arsenic concentrations less than $10 \mathrm{ppb}$; the arsenic concentration of a water from Muntinlupa sample had a value of $12.46 \mathrm{ppb}$. The levels of arsenic in this study are below 10 ppb because the water samples came from surface waters (Torres, 2010). Sacdal and Espino (2019) reported that arsenic levels in Laguna de Bay were below $10 \mathrm{ppb}$. The method used to analyze arsenic was hydride generation atomic absorption spectrophotometer (HG-
AAS). The difference in the results of our study against Sacdal and Espino (2019) was due to the difference in water source. Our study focused on groundwater while their study analyzed lake water. Arsenic is reported to be higher in groundwater than surface water like lake water. Usually, arsenic in lake water is attributed to geothermal water and mining activity (Mandal and Suzuki, 2002; Smedley and Kinniburgh, 2002). The findings of Sacdal and Espino (2019) do not support the results of the study of Molina (2011) on the heavy metal contamination of fish caught in Laguna de Bay. This study established fish from Laguna de Bay contained high levels of arsenic, lead, mercury, cadmium, and chromium. Moreover, among the five heavy metals, only arsenic is a confirmed human carcinogen (Class A) through the oral route of exposure. It is logical to attribute the high levels of heavy metals in fish to the lake environment, i.e. to the heavy metal contamination of the lake water.

The method used in this study has advantages over other analytical methods. First, our method can differentiate inorganic arsenic as As(III) and As(V) and can be used as an inexpensive alternative to LC-ICP-MS for speciation analysis of arsenic. By identifying the oxidation state of arsenic, the level of toxicity of arsenic in water can be assessed since $\mathrm{As}(\mathrm{V})$ is about six times less toxic than As(III) (Hughes et al., 2011). Second, the potentiostat, used in our study is durable and 
requires less maintenance and a lower skill requirement for the analyst compared with ICP-MS and HG-AAS which are more expensive than the potentiostat, require high maintenance cost and high level of expertise. Lastly, some voltammetric equipment are portable and can be used as a part of field operable portable equipment for rapid arsenic analysis.

\section{CONCLUSIONS}

The results showed that some of the groundwater samples from Bulacan, Batangas, and Laguna exceeded the maximum allowable limit of $10 \mathrm{ppb}$ total arsenic concentration set by the WHO and EPA. These results are quite alarming considering that people are actively using these groundwater supplies for drinking, cooking and other personal needs. Although, people living near the sampling sites may not manifest signs of arsenic poisoning, epidemiological studies should be conducted to assess how the incidence of cancer, diabetes and cardiovascular diseases in these areas compare to that of the general population. Arsenic poisoning usually manifests only after 10 to 20 years of chronic exposure.

This study also demonstrated the utility of an electrochemical method like DPASV for rapid, routine monitoring of arsenic contamination in water. This method offers the advantages of robustness, low cost, and low maintenance, coupled with low detection limits, qualities that are desirable in a field operable sensor for arsenic. Compared to atomic absorption spectroscopy and ion-coupled plasma analysis, techniques that require the services of a highly trained chemical analyst, DPASV requires a lower level of expertise from the analyst. In addition, the method can be used to determine speciation of arsenic present in a given water sample.

\section{ACKNOWLEDGEMENT}

The authors wish to thank the Philippine Council for Industry, Energy, and Emerging
Technology Research and Development (PCIEERD) of the Department of Science and Technology (DOST) for the financial support during the conduct of the study and the Commission on Higher Education (CHED) for the thesis support that was granted to the first author. We are also very thankful to Ms. Ma. Theresa Bea Glenn Manguiat, Ms. Stephanie Britania, and Mr. Immanuel Silverio for the prodigious help in water sampling and generating laboratory results. Moreover, we would like to thank Pure Earth, formerly called Blacksmith Institute Philippines, in helping us in finding water sampling sites and in lending us the multiparameter water quality checker.

\section{REFERENCES}

Arifin E, Cha J, Lee JK. Simple and efficient synthesis of iron oxide-coated silica gel adsorbents for arsenic removal: adsorption isotherms and kinetic study. Bull Korean Chem Soc. 2013 Aug 20; 34(8): 2358-2366.

Bodewig FG, Valenta P, Nurnber NW. Trace determination of $\mathrm{As}(\mathrm{III})$ and $\mathrm{As}(\mathrm{V})$ in natural waters by differential pulse anodic stripping voltammetry. Fresenius Z Anal Chem. 1982; 311:187-191.

Copeland TR, Skogerboe RK. Anodic stripping voltammetry. Anal Chem. 1974 Nov; 46(14): 1257A-1268A.

Environmental Protection Agency South Australia. 2019. Retrieved from: https://www.epa.sa.gov.au/environment al_info/water_quality/threats/salinity

Feeney R, Kuonaves S. Voltammetric measurement of arsenic in natural waters. Talanta. 2002 Aug 16; 58: 23-31.

Forsberg G, O’Laughin JW, Megargle, R.G... Determination of arsenic by anodic stripping voltammetry and differential pulse anodic stripping voltammetry. Anal Chem. 1975 Aug; 47(9): 1586-1592. 
Hughes MF, Beck BD, Chen Y, Lewis AS Thomas DJ. Arsenic Exposure and Toxicology: A historical perspective. Toxicol Sci. 2011 Oct; 123(2): 305-332.

Jain CK, Ali I. Arsenic: Occurrence, toxicity, and speciation techniques. Water Res. 2000 Dec; 34(17): 4304-4312.

Khan MA, and Ho Y. Arsenic in drinking water: A review on toxicological effects, mechanism of accumulation and remediation. Asian J Chem. 2011 Jan 3; 23(5): 1889-1901.

Mandal BK and Suzuki KT. Arsenic round the world: A review. Talanta. 2002 Aug 16; 58: 201-235.

Magalona ML, Peralta MM, Lacsamana MS, Sabularse VC, de Guzman CC. Optimization and validation of a differential pulse anodic stripping voltammetric (DPASV) method for trace analysis of inorganic arsenic in contaminated water. ISSAAS. 2018 June; 24(1):137-151.

Molina, VB. Health risk assessment of heavy metals bioaccumulation in Laguna de Bay fish products. 14th World Lake Conference, Austin Texas. 2011 July. Retrieve from: https://www.pref.ibaraki.jp/soshiki/seik atsukankyo/kasumigauraesc/04_kenkyu/ kaigi/docments/kosyou/14/2011wlc_vict oriob.molina.pdf

National Resource Defense Council (NRDC), Arsenic and old laws: A scientific and public health analysis of arsenic occurrence in drinking water, its health effects, and EPA's outdated arsenic tap water standard. 2000. Available from: http://www.nrdc.org/water/drinking/arseni c/appa.asp. [Accessed 25th July, 2015].

Office of the President of the Philippines. Creating an inter-agency task force on arsenic risk reduction and management. Manila: Malacañang Records Office; 2015 Aug 26. 2 p. Administrative Order No.: 47.
Robinson JW, Frame EMS, Frame GM. Undergraduate Instrumental Analysis. 6th ed. Marcel Dekker: New York; 2005.

Skoog DA, West DM, Holler FJ and Crouch SR. Fundamentals of analytical chemistry, 8th ed. Cengage Learning Asia; 2010

Sacdal RE, Espino MPB. Analytical determination and spatial distribution of arsenic in Laguna lake water. 34th Philippine Chemistry Congress; 2019 May 28 - 30; Waterfront Hotel and Convention Center, Cebu City (unpublished).

Salaun P, Planer-Friedrich M, van den Berg, C. Inorganic arsenic speciation in water and seawater by anodic stripping voltammetry with a gold microelectrode. Anal Chim Acta. 2007 Jan; 585: 312-322.

Santos TG. DOH warns vs arsenic in water supply. Philippine Daily Inquirer [newspaper on the internet]. 2016. July 1; Health: Available from:

http://newsinfo.inquirer.net/793616/do h-warns-vs-arsenic-in-water-supply

Philippine National Standards for Drinking Water (PNSDW). Department of Health, Republic of the Philippines. 2017.

Sun.Star Pampanga. Arsenic poisoning worries Pampanga town folk. Sun.StarPampanga [newspaper on the internet]. 2015, Feb. 28. Retrieved from: http://www.philippinesaddicts.com/forum/topic/57791-arsenicpoisoning-worries-pampanga-townfolk/\#

Sun.Star Manila. DOH on alert vs arsenic contamination in Central Luzon. Sun.Star Manila [newspaper on the internet]. 2016, June $30 . \quad$ Retrieved from: http://www.sunstar.com.ph/manila/local -news/2016/06/30/doh-alert-vs-arseniccontamination-central-luzon-482538 
Smedley PL, Kinniburgh DG. A review of the source, behavior and distribution of arsenic in natural waters. Appl Geochemistry. 2002 May; 17(5):517-568.

Sy SMT, Salud-gnilo CM, Yap-silva C, Tababa EJL. Report A retrospective review of the dermatologic manifestations of chronic arsenic poisoning in the Philippines. Int J Dermatol. 2017 Mar 28; 56(7):721-725.

Torres JRP, Banaag MKG, Rodriguez IB. A rapid method for simultaneous determination of arsenic, cadmium, and lead in drinking water by inductively coupled plasma mass spectrometry. Science Diliman. 2010 June; 22(1)1-8.

U.S. Geological Survey (USGS), Collection of water samples (ver. 2.0): U.S. Geological Survey Techniques of Water-Resources Investigations, book 9, chap. A4, September 2006, accessed [2018, Nov 8], at http://pubs.water.usgs.gov/twri9A4/.

World Health Organization (WHO), Guidelines for Drinking-Water Quality, WHO Press, Geneva, Switzerland, 4th edition, 2011. 